Pânico:

Contribuiçáo à psicopatologia dos atques de pânico

Mario Eduardo Costa Pereira

São Paulo, Lemos Editorial

1997

\title{
Contribuição à psicopatologia dos ataques de pânico
}

Maria Cristina Rios Magalhães

Ataques de pânico, síndrome de pânico, transtornos de pânico são, hoje em dia, cada vez mais conhecidos pelas pessoas em geral. Portadores de transtornos de pânico e especialistas no assunto freqüentemente são vistos, escutados e lidos através dos grandes meios de comunicação de massa debatendo o tema e relatando experiências ou vivências com estes ataques. Existem, também, os livros para leigos, escritos por especialistas, assim como os escritos pelos que sofrem dessa patologia.

Não é raro escutar pessoas se perguntando se estão doentes desses transtornos, já que detectam em si mesmas alguns dos sintomas propagandeados. Isto ocorre tanto dentro, quanto fora dos consultórios.

Atualmente, podemos dizer que esta instância da nosografia psiquiátrica já consta na lista das categorias médicas que fazem parte do uso corrente da língua e da linguagem popular.

Quando foi que ela surgiu? Em função de que necessidades ela foi criada? E, finalmente, no que ela 
consiste? Quais são as terapêticas utilizadas? Quais são os resultados que se tem obtido? Estas são questōes que nos ocorrem e que importam tanto aos especialistas, quanto respondem também ao interesse de muitos leigos.

Este livro, Pânico: Contribuição à psicopatologia dos ataques de pânico, aborda estas perguntas de uma forma clara e acessível, ao mesmo tempo que, do ponto de vista dos especialistas, seu autor trata do assunto de forma sóbria e em profundidade. Mário Eduardo Costa Pereira nos dá a conhecer, neste trabalho, uma vasta e interessante pesquisa bibliográfica, além de repartir com o leitor um capítulo de sua experiência e de seu alto nível na qualidade da reflexão clínica.

Foi através da clínica e da pesquisa que Mário Pereira se deparou com evidências que demarcavam os limites do pensamento atualmente hegemônico sobre os transtornos de pânico.

Num diálogo constante com a psiquiatria biológica atual e com seus avatares, o autor, através do uso freqüente de um fio histórico, nos põe em contato com os principais pensadores e pesquisadores deste assunto. Tendo como interesse e eixo orientador a psicopatologia, Mário Pereira faz um trajeto que começa na Grécia, passa pela Idade Média, Renascença e adentra no moderno e no contemporâneo. Transita na tradição ocidental. Passa por helenistas, filósofos, médicos e psicanalistas que se ocuparam da angústia, do medo, do pânico, do temor, do terror e do desamparo. Sua intenção é relativizar a primazia hierárquica do discurso e da prática hoje hegemônicos. Levantando alguns dos elementos essenciais, revela em múltiplas formulações e teorias concernentes a esse afeto, seu fundo propriamente psicopatológico. Assim ele nos enfronha nas principais discussōes e debates concernentes a estes estados.

Mostra-nos que a constituição da atual categoria psiquiátrica de transtorno de pânico inscreve-se numa tradição de práticas e pensamentos que tratou os fenômenos da angústia como eventos objetivos, captados somente em sua positividade, afastando-se, assim; da dimensão propriamente psicopatológica implicadas nestes transtornos.

Seu objetivo é descobrir nos textos da psiquiatria clássica, os laivos de sensibilidade teórico-clínicos que indicam caminhos pertinentes para uma elaboração num âmbito propriamente psicopatológico.

Apesar do pânico ser uma questão muito antiga para a humanidade, foi após 1980, com a publicação do DSM-III que o uso do termo passou a ser freqüente e sistemático. Mais tarde, a Classificação Internacional de Doenças (CID) também incorporou esta classificação diagnóstica. O pânico está no centro dos debates. Isto é algo novo. Tradicionalmente, ele sempre constou como evento em segundo plano. 


\section{RESENHAS}

Transtorno de pânico como categoria nosográfica, tal como é usada hoje em dia pela psiquiatria dominante, é uma categoria paradigmática de acordo com o modo de trabalhar desta tendência, a qual tomou enorme força após a década de 60 , com a revolução havida na psicofarmacologia.

$\mathrm{O}$ advento dos novos psicofármacos e suas pesquisas marcam o início das abordagens nosográficas operacionais em psiquiatria. $\mathrm{O}$ autor nos revela que $\mathrm{o}$ surgimento do transtorno de pânico está associado ao espírito que anima estas práticas e à abolição do debate psicopatológico em favor de um acordo pragmático.

Foi à partir dos trabalhos de Donald Klein e outros que esta categoria cunhou-se. Ela tem um fundamento pragmático essencialmente farmacoclínico. Originou-se da e para a discriminação de pacientes cujos sintomas eram susceptíveis de melhora com medicamentos a base de imipramina.

Dentre uma grande diversidade de formas de abordar o pânico e a angústia, Mário Pereira concentra seu trabalho principalmente nas contribuições da medicina e constitui a psicanálise na sua vertente freudiana, sua principal interlocutora. Neste âmbito, os trabalhos de Freud são considerados absolutamente relevantes não só para a psicanálise e seus múltiplos autores, como também para a psiquiatria, que foi longa e profundamente influenciada por esta.

Numa pērspectiva analítico-existencial, as contribuições de Ludwig Binswanger são examinadas também, através do seu clássico $O$ caso Suzan Urban. Este caso permite compreender a pertinência psicopatológica de uma abordagem não empírica dos estados de extrema angustia inclusive do pânico.

$\mathrm{O}$ autor termina seu trabalho especificando o estatuto do sintoma em psicanálise diferenciando-o do sintoma pensado pela psiquiatria. Sua conclusão é que o pânico é o inverso de um sintoma, se ele for pensado segundo a psicanálise

Através de Pierre Fédida, o sintoma é concebido como uma teoria do aparelho psíquico. O pânico não se apresenta assim, ele é antes de tudo o aniquilamento de toda organização psíquica. Aprofundando esta análise, Mário Pereira explicita a sua posição a respeito do tratamento do pânico através da clínica psicanalítica. 